\title{
Professores da educação básica rumo à uberização ou ao desemprego? Uma análise das relações de trabalho nas escolas estaduais da região metropolitana de Campinas
}

Selma Venco ${ }^{1}$

\section{Resumo}

O presente artigo visa debater a contratação de professores que atuam nos ensinos fundamental II e médio (PEBII), por vias distintas do concurso público, em cada escola estadual nos vinte municípios da Região Metropolitana de Campinas (RMC). A pesquisa, de caráter documental, analisou o fenômeno, característico da Nova Gestão Pública, à luz da localização das escolas no território e busca interrogá-lo, no sentido de compreender os caminhos futuros da profissão rumo à uberização ou ao desemprego. Verificou-se a existência de estreita relação entre a precariedade nas relações de trabalho e as áreas com maior vulnerabilidade social, em quantidade significativa de municípios. Palavras-chave: Política Educacional; Relações de Trabalho; Trabalho Docente; Vulnerabilidade Social.

Basic education teachers towards uberization or unemployment? An analysis of labor relations in state schools in the metropolitan region of Campinas

\section{Abstract}

This article aims to discuss the forms of hiring of teachers who work in middle and high school (PEBII), in different ways of the public tender, in each state school in the twenty municipalities of the Metropolitan Region of Campinas (RMC). The documentary research analyzes the phenomenon, typical of New Public Management, of the location of schools in the territory and seeks to interrogate it, in order to understand the future of the profession towards uberization or unemployment. It was found that there is a close relationship between precarious work and areas with greater social vulnerability, in a significant number of municipalities.

Keywords: Educational Policy; Work Relationships; Teaching Work; Social Vulnerability.

\section{Introdução}

O presente artigo é resultado de pesquisa mais ampla voltada à análise das relações de trabalho ${ }^{2}$ praticadas entre docentes na França e no Brasil, segundo o território. Apresenta-se aqui um recorte geográfico, visando focalizar o fenômeno nas escolas da rede estadual da Região Metropolitana de Campinas (RMC). Pressupôs-se, inicialmente, que as áreas com maior vulnerabilidade social são concentradoras de maior número de contratos precários entre os

\footnotetext{
${ }^{1}$ Professora da Faculdade de Educação da Unicamp, pesquisadora associada do Centre de Recherches Sociologiques et Politiques de Paris (CRESPPA) e vice-líder do Grupo de Estudos e Pesquisas em Política Educacional (GREPPE). Campinas, svenco@unicamp.br.

2 Pesquisa financiada pela FAPESP, Processo no 2019/015552-3.
} 
docentes. Para tanto, procedeu-se à verificação dos dados concernentes ao setor censitário no plano micro da pesquisa, qual seja, a RMC, a qual reúne vinte municípios com características diversas e totaliza 3.255.923 habitantes (IBGE, 2020).

De caráter documental, a investigação articula em sua análise: os marcos legais, os dados estatísticos oriundos da Secretaria da Educação do estado de São Paulo (SEDUC-SP), concernentes às formas de contratação dos docentes para o cargo de Professor da Educação Básica II (PEBII), que atuam junto aos Ensinos Fundamental II e Médio e, por fim, a distribuição espacial das escolas, com vistas a averiguar a hipótese aventada.

Adotou-se o Índice de Vulnerabilidade Social Paulista (IVSP) elaborado pela Fundação SEADE (SEADE, 2016), a partir dos dados do censo demográfico, mais especificamente do setor censitário. Este é construído por meio de modelo de análise fatorial, reúne variáveis relativas às condições socioeconômicas (escolaridade do responsável pela família, quantidade média de anos de estudo e rendimento nominal médio do responsável pela família); e ciclo de vida das famílias (gênero do responsável pela família, número de crianças de 0 a 4 anos no setor censitário, saneamento básico e coleta de lixo). A conjugação de ambos resulta em escala de vulnerabilidade de baixíssima a muito alta.

\section{Contratação flexível de professores: uma permanência histórica}

A passagem do trabalho escravo ao livre delineia os primeiros traços do mercado de trabalho no Brasil e, com ela e leis que, em 1850, concederam terras à ocupação por homens livres, exceto para ex-escravos. Assim, como destaca Dedecca (2005), o trabalho subordinado tem suas origens no país e carrega esse traço até a atualidade.

Coetaneamente, no século XIX, o presidente da Província de São Paulo visou regular o trabalho dos professores públicos e, por meio da Lei 81, a qual em seu art. 18 indica que esses: "são nomeados pelo presidente da província, mediante concurso feito perante a secção competente do conselho" (1887, s/p) e teriam seus cargos em regime vitalício. E, em casos de impedimento, inferior ou igual a trinta dias, seria nomeado um substituto.

Apreende-se a dificuldade brasileira, ao longo da história, em romper com a presença do Estado Patrimonialista no país, o qual sustenta-se na arbitrariedade e é legitimado pela tradição. 
Para Faoro (1988), o patrimonialismo adotado no Brasil, associado ao colonialismo, confere explicação sobre os desdobramentos políticos no país.

No caso dos docentes, o patrimonialismo presente no século XIX é verificado na previsão para contratações, via apadrinhamento, baseado nos compromissos políticos e ou outras formas de contratos atípicos. Assim, apreende-se que ao longo dos anos conviveram profissionais exercendo as mesmas funções e com as mesmas responsabilidades, porém com salários e direitos diferenciados.

A terceira Constituição Federal do Brasil, em 1934, indica, pela primeira vez, a obrigatoriedade para admissão de funcionários públicos por concurso público, mas já prevendo uma contratação atípica:

Art 158 - É vedada a dispensa do concurso de títulos e provas no provimento dos cargos do magistério oficial, bem como, em qualquer curso, a de provas escolares de habilitação, determinadas em lei ou regulamento.

$\S 1$ ㅇ - Podem, todavia, ser contratados, por tempo certo, professores de nomeada, nacionais ou estrangeiros.

O ingresso por concurso público constará, igualmente, nas Constituições de: 1937 (art. 156); 1946, que além de assegurar a obrigatoriedade admissional por concurso, reconhece a vitaliciedade do cargo e a liberdade de cátedra (Capítulo II, Incisos VI e VII); 1967 (Seção VII, art.95, § 2ㅇ); e, por fim, na de 1988 (art. 37):

II - A investidura em cargo ou emprego público depende de aprovação prévia em concurso público de provas ou de provas e títulos, de acordo com a natureza e a complexidade do cargo ou emprego, na forma prevista em lei, ressalvadas as nomeações para cargo em comissão declarado em lei de livre nomeação e exoneração.

A despeito do regido no conjunto de Constituições, o governo paulista criará, no intervalo das promulgações, uma lei que não só reconhece o trabalho não contratado por concurso público, como irá nominar a precariedade nas relações de trabalho ao reconhecer, na Lei 500 de 1974, a admissão de docentes não efetivos, a partir de então classificados como admitidos em caráter temporário (ACT).

É nesse cenário - voltado à análise das relações de trabalho e à precariedade nelas 
expressas - que as reflexões são tecidas no presente artigo. Assim, é imperativo destacar a adesão teórica ao conceito de relações de trabalho, com base em Delgado (2007), que o compreende, no âmbito do direito administrativo, como responsável por regular o contrato a ser firmado entre empregador e trabalhador ao contemplar direitos, jornada, salário, benefícios, quando houver. Portanto, é aqui considerado distinto de outro conceito, qual seja, as condições de trabalho. Essas são expressas tanto pelas condições ambientais dos locais de trabalho, mas também pela organização e gestão do trabalho, a exemplo das formas de pressão para aumento da produtividade e alcance de resultados pré-estabelecidos (GOLLAC, VOLKOFF, 2007).

Da mesma forma, se recorre ao conceito de precariedade nas relações de trabalho, pouco presente na literatura nos anos 1970 embora com algumas tentativas de definição, a exemplo das formuladas por Robert Linhart (1978) ao afirmar que a precariedade era elemento central para cindir os trabalhadores. Será ao final dos anos 1980 e durante a década de 1990 que o conceito ocupará lugar singular nas análises sobre o mundo do trabalho, que vivenciava, à época, uma transformação importante tanto pelo avanço da microeletrônica, quanto pela adoção de uma organização do trabalho mais concisa e defensora da flexibilização dos contratos, como resposta à oscilação da demanda aos moldes do toyotismo (GOUNET, 1999). Gerry Rodgers, economista da Organização Internacional do Trabalho (OIT), pondera que "raramente as formas precárias de contratação estiveram ausentes do emprego assalariado" (1989, p. 1) $)^{3}$. Para ele, o oeste europeu construiu o emprego mais estruturado no período compreendido entre o final da Segunda Guerra Mundial e meados dos anos 1970, sustentado por acordos coletivos e o estabelecimento de direitos aos trabalhadores e, com isso, a formação da conscientização da população sobre eles. Há, para o autor, muitas dimensões da precariedade, quais sejam: o grau de inconstância do vínculo; esse é inseguro e, principalmente, se caracteriza como um trabalho desprotegido de direitos, de defesa contra discriminações e práticas salariais desprovidas de similaridade com os pares. Para Rodgers $(1989$, p. 3) "o conceito de precariedade envolve instabilidade, ausência de proteção, insegurança e vulnerabilidade social e econômica"4

Robert Castel (1998), anos depois, ao examinar a sociedade salarial francesa concebe a precariedade de forma similar à de Rodgers, mas destacando-a como um fenômeno das relações

\footnotetext{
${ }^{3}$ Precarious form of work rarely been absent from systems of wage employment.

${ }^{4}$ (...) the concept of precariousness involves instability, lack of protection, insecurity and social or economic vulnerability".
}

Periódico Horizontes - USF - Itatiba, SP - Brasil - e021035 
de trabalho, que, por conseguinte, conduz à precarização das condições de vida. Além disso, nomeia os contratos por tempo determinado, o trabalho part-time, os estágios e outras formas ainda mais fragilizadas de direitos, cuja conclusão do autor remete à exaustão dos coletivos, ocasionado tanto pelo vínculo empregatício efêmero, quanto pelo temor ao desemprego de longa duração.

\section{A precariedade entre docentes: do Brasil à região metropolitana de Campinas}

O censo educacional realizado pelo Instituto Nacional de Estudos e Pesquisas Educacionais Anísio Teixeira (INEP) passou a coletar informações a respeito das formas de contratação dos docentes apenas a partir de 2011, agrupadas em quatro categorias: concursados, terceirizados, temporários e contratados pela Consolidação das Leis do Trabalho (CLT) (INEP, 2011, 2019).

Em termos de Brasil é possível afirmar que treze dos vinte e seis estados e Distrito Federal registram movimento crescente de docentes não concursados. Entre esse grupo destacam-se Acre e Espírito Santo com praticamente oito em cada dez docentes em situação de contrato precário. Outros dez estados apresentam percentuais estáveis ao longo da série histórica, mas não por essa razão deixam de ser elevados, a exemplo da Ceará e Mato Grosso, cada um com média de $60 \%$ de professores não efetivos e, por fim, apenas três (Amazonas, Rio Grande do Norte e Sergipe) adotaram políticas de reduzir os contratos precários (VENCO, 2020).

O estado de São Paulo encontra-se entre aqueles com percentuais decrescentes, porém, há disparidade importante entre os dados coletados pelo Inep e os fornecidos pela Seduc-SP: "considerando o período coletado pelo censo educacional, 2011 a 2018, constata-se haver uma média de contratos precários da ordem de $21 \%$, enquanto pelos dados da própria Secretaria a média é pouco acima do dobro, 40\% (...)" (VENCO, SOUSA, 2021, p.78).

Concernente ao estado de São Paulo, desnecessário reafirmar ser este o mais industrializado e rico de todo o país, tendo registrado, em 2019, Produto Interno Bruto (PIB) de R\$ 2.210 trilhões, seguido pelo Rio de Janeiro com R\$ 758,859 bilhões (IBGE, 2020) e indica, portanto, a magnitude de São Paulo. Poder-se-ia pressupor que tal pujança na economia refletisse na implementação de políticas sociais, capazes de retroalimentar a vocação paulista de desenvolvimento econômico. 


\section{HSE}

Todavia, a política educacional adotada pelo estado paulista, mormente a partir de 1995, orienta-se pelos princípios gerencialistas focados na racionalidade econômica, na meritocracia e na legitimação dos valores empresariais na administração pública. É concretizada via adoção de materiais e aulas padronizadas, com forte controle sobre o trabalho docente e avaliações em larga escala, que consistem em provas homogêneas para contextos heterogêneos (VENCO, 2019).

Uma das expressões da racionalidade econômica reside na flexibilização nas formas de contratação dos docentes - acompanhando o movimento das empresas, no Brasil, nos anos 1990 -, quando em 1999 o estado de São Paulo teve em média 72\% de docentes não concursados (VENCO, 2020).

A análise da concentração de relações de trabalho precário nas escolas paulistas indica que essas prevalecem na faixa compreendida entre 30,1 e $45 \%$, seguida do segmento de 45,1 a $60 \%$, em toda a série histórica. Ambas somadas apontam a marca de praticamente 7 em cada 10 escolas nessa situação (Gráfico 1).

Gráfico 1. Distribuição de escolas estaduais paulistas, segundo escala de docentes da educação básica não-efetivos (no abs)

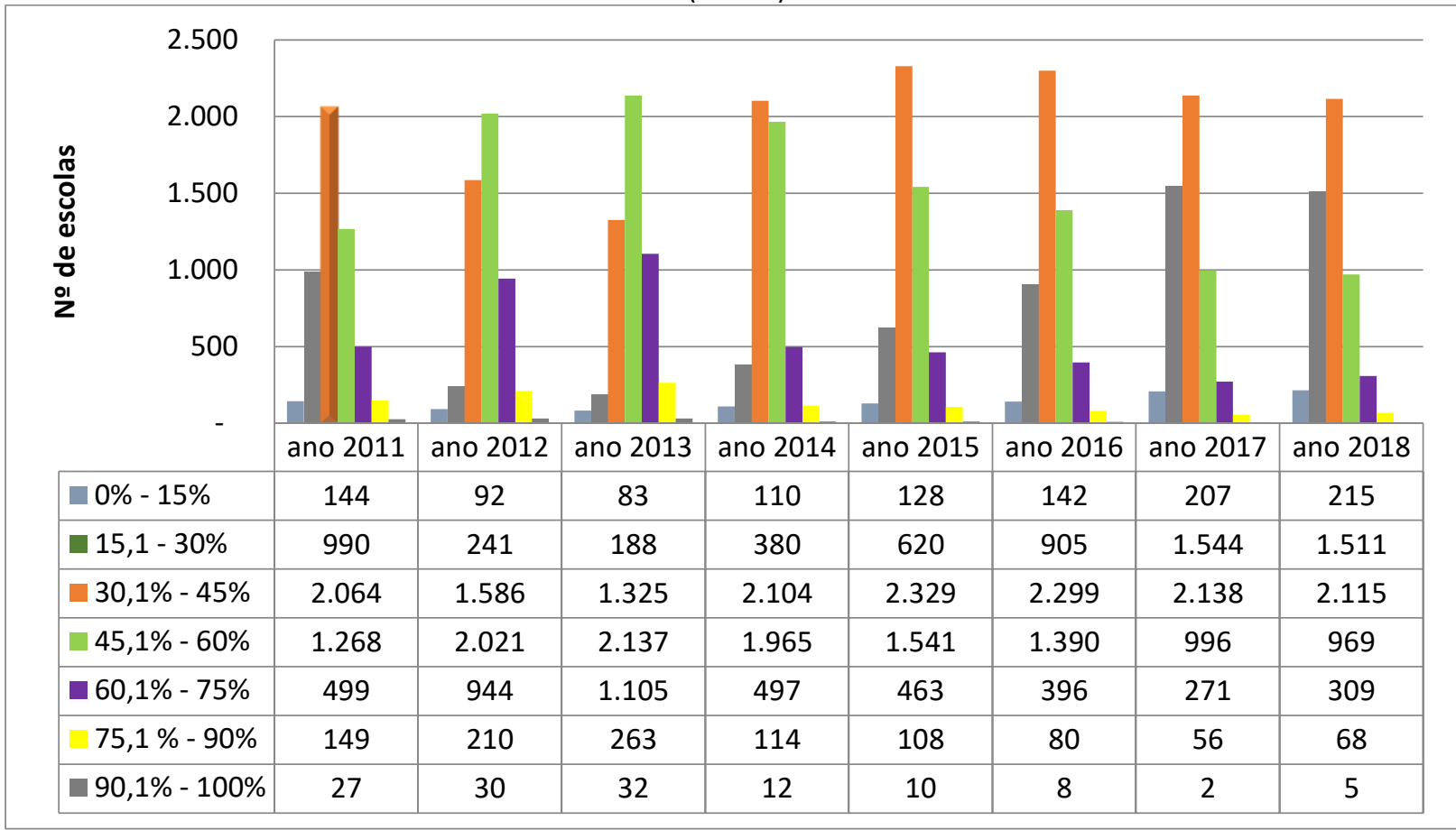

Fonte: SEDUC-SP, CGRH, 2011 a 2018 
Os números oscilam com a realização de parcos concursos (VENCO, 2016) e com oferta de vagas em quantidade inferior à real necessidade de suprir os contratos instáveis. Assim, tem mantido ao longo dos anos uma média de $51 \%$ de contratos a baixo custo. Constata-se, com base nos dados fornecidos pela Seduc-SP, que a partir de 2015 esses percentuais entram em declínio.

Entretanto, tal movimento não reflete a adoção de uma política específica de avanço de vínculos estáveis e ou mediante a realização de concursos públicos, e principalmente na melhoria das condições de trabalho dos docentes e de aprendizagem dos estudantes, a exemplo da redução de número de alunos por turma. Ao contrário, houve pressuposta degradação das condições de trabalho, pois se amplia o número de alunos por turma e ocorre o fechamento de escolas e o estímulo à extinção do ensino noturno. Corrobora a análise o fato de que, desde 2019, as diretorias regionais de ensino paulista passaram a receber, do gabinete do Secretário, cotas de contratos possíveis de serem firmados junto aos docentes em caráter eventual e ou temporário. Pondera-se, entretanto, que, com tal medida, há, segundo consultas realizadas em algumas diretorias de ensino, escolas sem aula e ou crianças e jovens agrupados em outras turmas, aspectos esses que, certamente, comprometem a relação ensino-aprendizagem e, por consequência, o trabalho do professor.

\section{A relação entre a precariedade das relações de trabalho e o território}

A articulação de alguns indicadores socioeconômicos dos municípios integrantes da Região Metropolitana de Campinas (RMC) às formas de precariedade praticadas em cada escola recai sobre a compreensão do território. Dadas as características da RMC já sumariamente apresentadas na introdução do presente artigo, privilegiou-se abordar o porte populacional de cada um deles e o Índice Paulista de Vulnerabilidade Social (IPVS), ambos associados aos percentuais de precariedade nas relações de trabalho dos docentes praticadas pelo governo paulista.

O enfoque no território pressupôs, com base em Harvey (2006), a existência de uma produção capitalista do espaço, com ajustes cíclicos de alocação e realocação das empresas que afetam a distribuição espacial do capital e, consequentemente, da população. Assim, ao movimento pendular da valorização e da desvalorização territorial, outro semelhante lhe é 
intrínseco: criar e destruir empregos, equipamentos sociais e, assim, tece-se uma hierarquização do acesso ao espaço, com consequente interferência nas relações de trabalho.

Conforme Singer (1982), a especulação imobiliária incrementa as regiões com boa infraestrutura e relega à população de baixa renda outras desprovidas das mesmas condições, mas não necessariamente configurando o binômio centro-periferia. Nery, Souza e Adorno (2019) destacam que a classificação centro-periferia se altera vigorosamente na atualidade e indagam a adequação do termo no atual estágio do capitalismo e ponderam: "as cidades não estão partidas entre bairros ricos e pobres; há uma heterogeneidade urbana na qual tais bairros são criados de modo contíguo, estabelecendo, ou não, comunicação entre seus moradores, serviços e usos do território" (NERY; SOUZA; ADORNO, 2019, p.7-8).

Com base nessas reflexões intenciona-se estabelecer nexos entre certas características territoriais e a presença de professores temporários vinculados à rede paulista.

Para o recorte populacional, adotou-se o critério do IBGE (2004) que classifica os municípios em sete agrupamentos. E, dentre os vinte municípios integrantes da RMC, Holambra e Morungaba apresentam população entre 10.001 e 20.000 habitantes.

Holambra tem como principal atividade econômica a cultura de flores e de plantas ornamentais e população de pouco mais de 15.272 habitantes (IBGE, 2020). Seu IDHM é de 0,793 e renda per capita de $\mathrm{R} \$ 1.274,53$ (IBGE, 2018), ambos acima da média dos municípios do estado de São Paulo, 0,793 (IDHM) e R\$ 853,75, respectivamente.

Morungaba registra população de 13.781 habitantes (IBGE, 2020) e IDHM de 0,715. Os empregos formais encontram-se predominantemente no setor de serviços (49,67\%), seguidos do

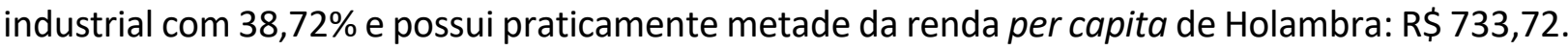

Em relação aos docentes, a série histórica construída a partir de 2011, ano em que a Seduc-SP forneceu dados acerca das formas de contratação por escola, observa-se ao longo da série histórica que havia em Holambra 50\%, em média, de professores contratados temporariamente; a partir de 2017 exibe redução importante e atinge pouco mais de 20\%. Já Morungaba, registrou movimento diverso: em 2011, quatro em cada dez docentes eram não concursados e, posteriormente sofre ligeiro aumento: $45 \%$ em 2017. Congruente ao movimento decrescente de contratos flexíveis no estado, chega em 2019 a 35\%, como pode ser observado no Gráfico 2. 
Gráfico 2. Docentes PEBII, não concursados, média anual, rede estadual paulista, municípios com população entre 10001 a 20.000 hab., 2011 a 2019 (\%)

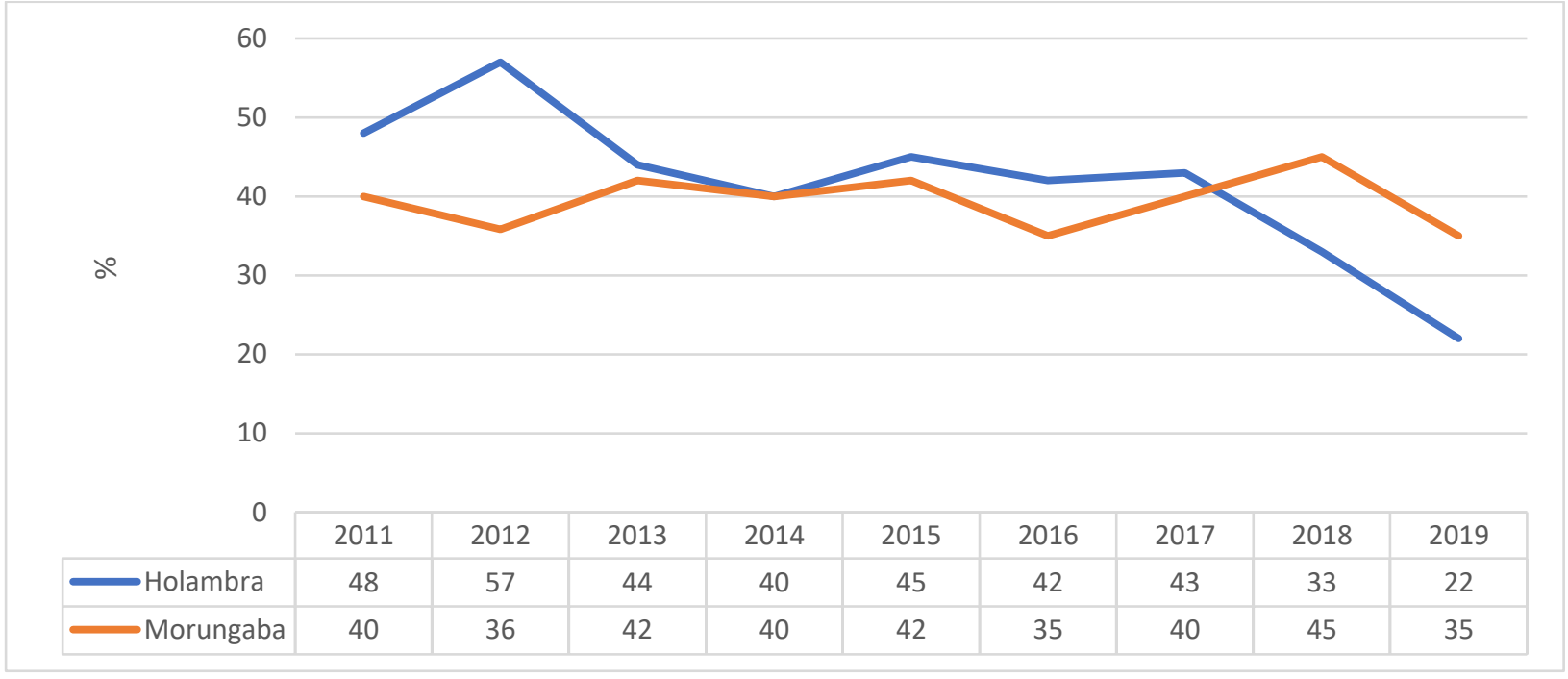

Fonte: SEDUC-SP, CGRH, 2011 a 2019. Elaboração própria.

A hipótese que relaciona municípios mais pobres à maior precariedade entre docentes se confirma no segmento populacional seguinte, que compreende população entre 20.001 a 50.000 habitantes. São eles: Engenheiro Coelho, Pedreira e Santo Antônio de Posse.

O município de Engenheiro Coelho tem população de 21.249 habitantes (IBGE,2020), com renda per capita de $\mathrm{R} \$ 707,37$ (IBGE, 2018) e o IDHM 0,732. A maior concentração dos empregos formais está na indústria $(25,5 \%)$, seguida pelo comércio atacadista e varejista e do comércio de reparação de veículos automotores e motocicletas $(14,84)$. Tal caracterização dialoga com o registro de elevado percentual médio de $48 \%$ docentes temporários na série histórica. Destaque-se que entre 2012 e 2016 seis a cada dez professores possuíam contratos instáveis. A observância da única escola do município informa que em 2011 havia 37\% de contratos precários e em 2019, contrariando a movimento mais geral do estado passa para $47 \%$.

Pedreira com 48.463 (IBGE, 2020) habitantes e renda per capita de $\mathrm{R} \$ 853,76$, registra IDHM de 0,769. Os empregos formais concentram-se na Indústria com 51,45\%, em especial na fabricação de objetos de porcelana e louça, seguida do setor de serviços com $25,02 \%$ e Comércio Atacadista e Varejista e do Comércio e Reparação de Veículos Automotores e Motocicletas com 22,32\%. Entre os três municípios do grupo, é o que apresenta os menores percentuais de contratos precários entre eles: inicia em 2011 com 34\% e finaliza, em 2019 


\section{HSE}

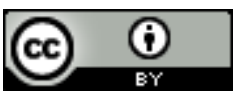

com $16 \%$. Entre as quatro escolas estaduais existentes, constata-se que a EE Cel. João Pedro Moreira ampliou de 38\% em 2011 para 49\% de contratos precários em 2019, o percentual mais elevado; e a EE João Alvarenga teve percentual estável, mas ainda assim, de 38\% nos anos inicial e final.

Santo Antônio de Posse com população de 23.529 habitantes (IBGE, 2020), com renda per capita de $\mathrm{R} \$ 673,38$ e $1 / 3$ da população percebe até $1 / 2$ salário-mínimo. Os empregos formais são majoritariamente no comércio atacadista e varejista e do comércio de reparação de veículos automotores e motocicletas $(23,21 \%)$, seguido pela indústria $(19,62 \%)$, agricultura e pecuária, produção florestal, pesca e agricultura (15,72\%) e construção civil (4,96\%). 0 município possui uma única escola e inicia a série histórica, em 2011, com 43\% de professores temporários, e apresenta efetiva redução dos percentuais em 2019, terminando a série com 24\%. (Gráfico 3).

Gráfico 3 - Docentes PEBII, não concursados, média anual, rede estadual paulista, municípios com população entre 20.001 a 50.000 hab., 2011 a 2019 (\%)

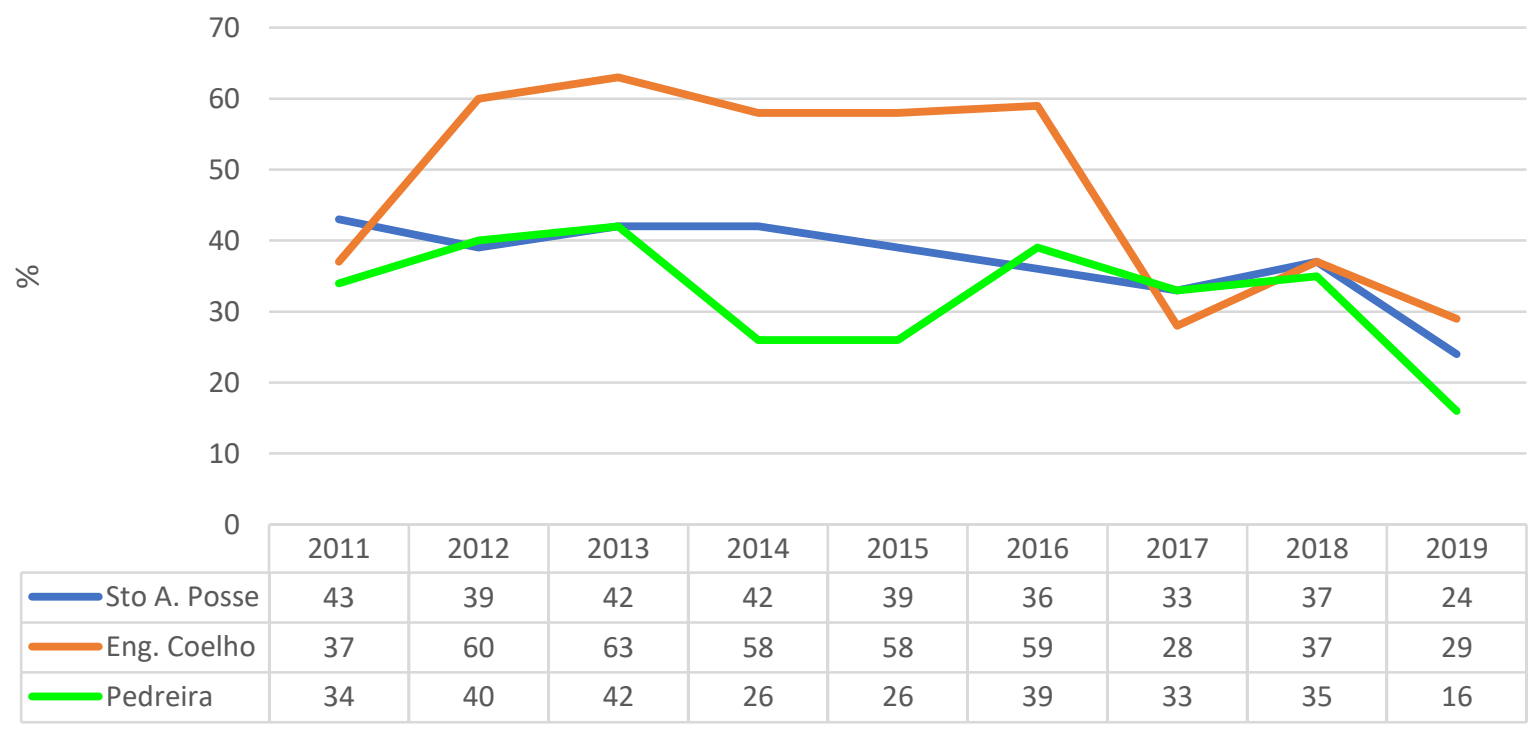

Fonte: SEDUC-SP, CGRH, 2011 a 2019. Elaboração própria.

Constata-se que a Região Metropolitana de Campinas é composta por municípios mais populosos, pois o agrupamento populacional, que congrega entre 50.001 e 100.000 habitantes, é representado por seis deles: Artur Nogueira, Cosmópolis, Jaguariúna, Vinhedo, Monte Mor e Nova Odessa. 
Artur Nogueira tem população de 55.340 habitantes e, nesse grupo, é o que registra menor percentual de pessoas ocupadas (19,3\%) e renda per capita: $\mathrm{R} \$ 661,52$ (IBGE, 2010). Vale informar que menos de $1 / 3$ da população (28\%) possui renda até $1 / 2$ salário-mínimo e pouco menos de $20 \%$ da população é ocupada (IBGE,2010). O IDHM de 0,749 e pouco mais de $5 \%$ da população não alfabetizada contribuem para uma caracterização socioeconômica concentradora de pobreza. É o que apresenta a mais elevada presença de precariedade e alça, em 2017, praticamente sete docentes em cada dez como não efetivos. Entre as quatro escolas do município duas delas (Armando Falcone e Amaro Rodrigues) aumentaram os percentuais de precariedade de 35 para $42 \%$ e de 19 para $37 \%$, respectivamente. Enquanto as demais (José Aparecido Munhoz e Magdalena Grosso) reduziram de 33 para 20\% e de 41 a $32 \%$.

Nova Odessa, com 60.956 habitantes (IBGE, 2020), tem IDHM de 0,791 e R\$ 733,41 de renda per capita. A despeito de Nova Odessa registrar salário médio pouco abaixo de Monte Mor, 3,1 e 3,2 salários-mínimos respectivamente, há diferença significativa no percentual de pessoas ocupadas: 35, 3\% em Nova Odessa contra 23,9\% em Monte Mor. Todavia, entre ambos, é em Nova Odessa que há maior número de docentes não concursados. A verificação dos percentuais na série história indica que entre as cinco escolas do município, apenas uma (Joaquim Rodrigues Azenha) ampliou a presença de contratos temporário em 16 pontos percentuais, pois passou de 31\%, em 2011, para 47\% em 2019.

Cosmópolis possui 73.474 habitantes (IBGE, 2020) apresenta renda per capita de $\mathrm{R} \$ 703,59$ e IDHM de 0,769. A maior concentração dos empregos formais encontra-se na indústria $(28,28 \%)$, seguida pelo comércio atacadista e varejista e do comércio de reparação de veículos automotores e motocicletas $(21,42 \%)$ e construção civil $(5,31 \%)$. O município, por razões passíveis de serem aprofundadas, teve a mais importante redução no número de docentes temporários e encerra a série histórica em 2019 com a média de 9\% de professores nessa situação. Ainda assim, a escola Lidia Crepaldi registrava 41\% de contratos precários em 2019, antes em 2011 com 48\%; e Celio Rodirgues Alves que decaiu de $59 \%$ para $32 \%$, no mesmo período.

O município de Monte Mor com 60.754 habitantes (IBGE, 2020), tem renda per capita (IBGE, 2010) baixa em relação à observada na $\mathrm{RMC}: \mathrm{R} \$ 548,32$. O setor de serviços responde pela maior quantidade de empregos (42\%), seguida pela indústria (34\%). 
Das sete unidades escolares existentes, quatro ampliaram os contratos temporários, a exemplo da Escola Estadual Prof.a Joana A. Marins Peixoto cujo percentual em 2011 era de 55\% e passa para $61 \%$ em 2019. Duas outras, Elias Massud e Mario Covas apresentam percentuais de 55 e $50 \%$ de professores instáveis nas escolas.

Distintamente em relação ao segmento populacional ao qual pertence, Jaguariúna possui histórico de Produto Interno Bruto (PIB) per capita elevado, dada a presença de grandes indústrias como AMBEV e Motorola. Tem população de 54.722 (SEADE, 2020) habitantes. O município possui renda per capita de R\$ 854,67 (IBGE, 2010). O IDHM de 2010 atingiu um índice de 0,721. A população ocupada é elevada: $63,3 \%$ e os empregos formais com maior concentração ocorrem na indústria e nos serviços: $39,40 \%$, e 47,52\% respectivamente.

São três escolas estaduais no município, sendo que duas delas reduziram os percentuais de contratação temporária: EE Julia Calhau Rodrigues com praticamente metade do corpo docente precário em 2011 (48\%) e reduz para 21\% em 2019; na EE Anna Calvo de Godoy passa de 38 para 29\% no mesmo intervalo. Apenas a EE Celso Tozzi amplia ligeiramente os contratos temporários de 17 para 21\% entre 2011 e 2019.

Jaguariúna juntamente com Vinhedo - com população de 80.111 habitantes (IBGE, 2020), renda per capita de $\mathrm{R} \$ 1.493,32$ e taxa de analfabetismo inferior à do estado (3,73\%) -, ambos com as mais elevadas taxas de população ocupada e com o maior salário médio no grupo, possuem, inversamente, os menores percentuais de precariedade entre os professores.

Todavia, as três escolas de Vinhedo apresentaram crescimento dos percentuais de precariedade, ainda que abaixo da média da RMC. 


\section{HSE}

Gráfico 4. Docentes PEBII, não concursados, média anual, rede estadual paulista, municípios com população entre 50.001 a 100.000 hab., 2011 a $2019(\%)$

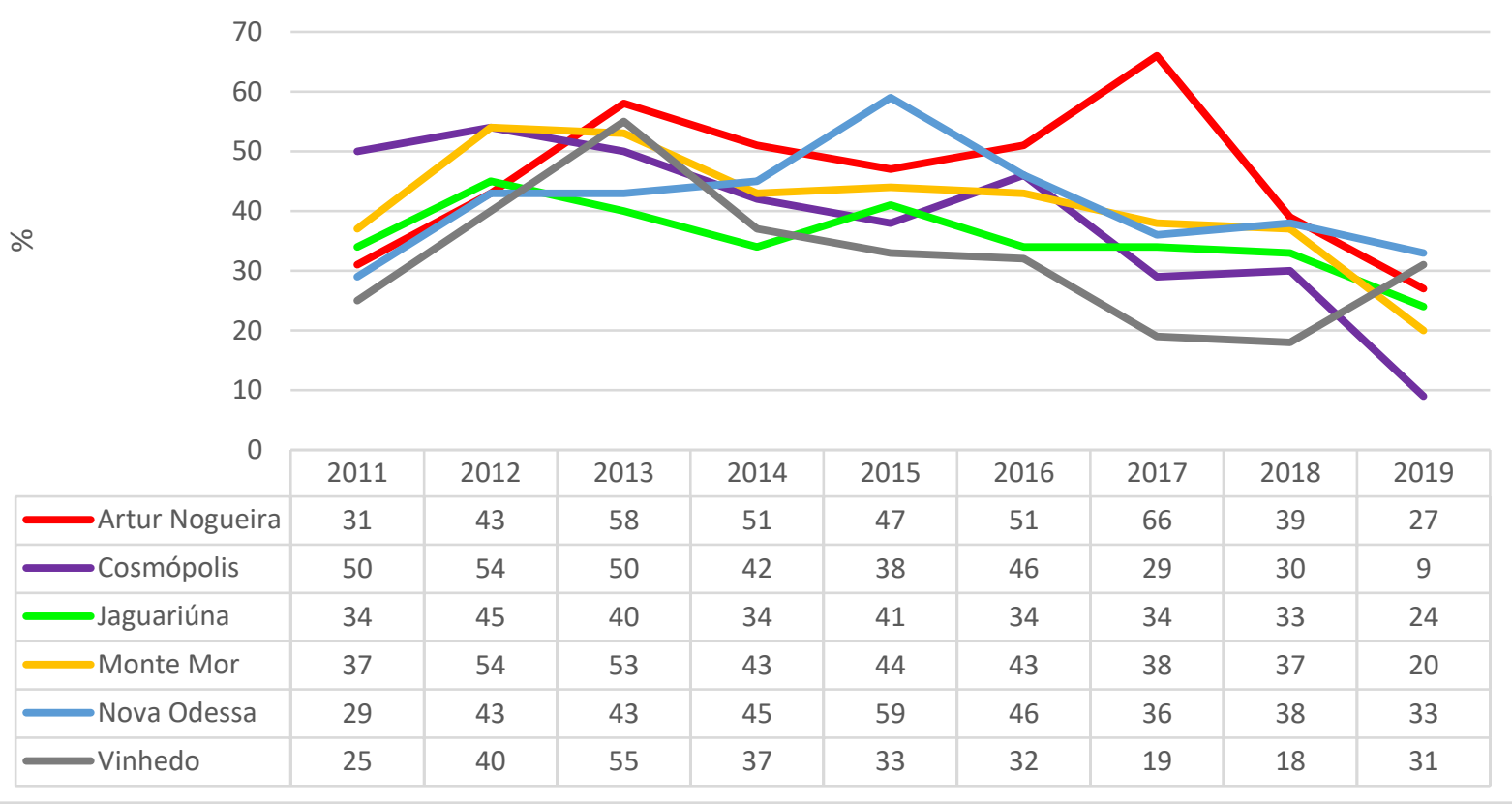

Fonte: SEDUC-SP, CGRH, 2011 a 2019. Elaboração própria.

O agrupamento populacional de municípios entre 100.001 e 500.000 habitantes, reúne oito dos vinte municípios da RMC.

Americana possui população estimada de 242.018 (IBGE, 2020) IDHM elevado: 0,811. A renda per capita é, da mesma forma, superior: $\mathrm{R} \$ 996,61$. O município concentra forte produção têxtil, mas o maior número de empregos encontra-se no comércio. Ao longo da série histórica registra média de 41\% de docentes precários, alcançando em 2016 sua maior média: $50 \%$.

A média, entretanto, oculta certas situações. Das 32 escolas estaduais presentes no município, 21 ampliaram seus contratos temporários. Destaque-se a EE João Solidário com o quadro mais grave, pois atravessa todo o arco temporal pesquisado com elevados percentuais de docentes não efetivos: em 2011 eram 63\% e em 2019, 74\%, contrariando a média estadual; outras sete registram percentuais acima de 50\% em 2019. Destacadamente a EE Hylda Pardo Oliveira com $69 \%$ no mesmo ano e EE Antonieta Lenhare com $61 \%$.

Santa Bárbara d’Oeste com população, 194.390 habitantes (IBGE, 2020); IDHM (0,781) e renda per capita (R\$ 730,23), apresenta média de docentes não efetivos entre 2011 e 2019 de 43\%, com ápice em 2012: 49\%. 
Das 34 escolas estaduais do município, pouco mais da metade - 16 delas - ampliaram os contratos temporários. Em 2019, a EE Luzia Baruque contava com praticamente 7 em cada 10 docentes nessa condição. Cabe destacar, contudo, que certas escolas atravessaram nove anos com percentuais importantes de precariedade. São elas: Dirceu Dias Carneiro que passa de $45 \%$ em 2011 para 57\% em 2019; Maria Judita Oliveira, de 55\% para 61\% e Laura Emmie Pyles que salta de 50 para $62 \%$.

Indaiatuba, município em expansão, tem população de 256.223 (IBGE, 2020). Com renda per capita inferior à de Americana, $\mathrm{R} \$$ 931,09, concentra grandes indústrias, sobretudo automotivas e mecânica e importante foco de geração de empregos no comércio varejista e IDHM de 0,788. Não obstante, o vigor econômico do município não se reflete nos cargos concursados para professores: em 2019, Indaiatuba registrou o segundo maior percentual médio de contratos precários nas escolas (37\%). Entre as 19 escolas, seis delas ampliaram os contratos temporários na série histórica. Chama a atenção a EE Jardim Morada do Sol que não havia nenhum professor concursado em 2011; e, em 2019, esse percentual é reduzido pela metade, mas ainda assim é acima da média da RMC.

Hortolândia e Sumaré são compreendidas por Moreira Júnior (2015) como cidadesdormitório, posto que a população - pela proximidade a Campinas e facilidades de deslocamento, reside em pequenos municípios e trabalha em grandes centros urbanos. Constata-se, assim, que Hortolândia possui 256.223 habitantes (IBGE, 2020), renda per capita de $\mathrm{R} \$ 552,57$ (IBGE, 2010) e IDH de 0,79. Sumaré, por sua vez, com população de 286.211 (IBGE, 2020), ambas lideraram as médias de professores precários nas escolas estaduais em toda a série histórica, exceto em 2019, lugar ocupado por Itatiba (Gráfico 5).

Dentre as 20 unidades escolares de Hortolândia, apenas duas delas ampliaram seus percentuais de contratação temporária. São elas: EE Honorino Fabbri - que já contava com 40\% de professores nessa situação e amplia para 65\% em 2019; e, EE Yasuo Sasaki que inicia em 2011 com $57 \%$ e amplia para 59\%, em 2019. Não obstante, o contexto geral de precariedade entre docentes é constante e elevado, a exemplo da EE Maristela Mellin que reduziu de 71\% em 2011, mas ainda seis em cada dez professores são não efetivos.

Sumaré conta com 35 escolas estaduais, dentre as quais 14 registraram, em 2011, percentuais acima de $50 \%$ referentes aos contratos temporários. É importante problematizar o 
funcionamento da escola, a relação ensino-aprendizagem e a instabilidade dos docentes em escolas a exemplo das: EE Zoraide Proença Kaysel que em 2019 tinha 82\% do corpo docente em caráter temporário; da EE Luis Henrique Marchi, com 77\% e, ainda, a EE Ana Lucia Pierini, com $70 \%$ no mesmo ano.

Itatiba registra renda per capita equivalente ao dobro de Hortolândia e Sumaré (R\$1.049,74, IBGE, 2020) e metade da população (116.365, IBGE, 2020). O município vem recebendo fortes investimentos decorrentes da instalação de indústrias que se deslocam da Região Metropolitana de São Paulo para outras próximas da RMC (SEADE, 2020) e, com isso, teve aumentos substanciais nos empregos formais no comércio e na indústria. Nesse cenário, Itatiba conservou as médias mais reduzidas, entre os municípios de mesmo porte populacional, de professores temporários, exceto, como já indicado, em 2019, apresentando movimento inverso à tendência estadual e regional.

Com apenas quatro escolas estaduais, essas mantiveram percentual praticamente inalterado nas contratações temporárias e registra na EE Oscarlina Oliveira o maior percentual em 2019, de $22 \%$.

O município de Valinhos persegue o movimento de Itatiba em relação à precariedade nos contratos entre docentes das escolas estaduais. Com população também similar de 131,210 habitantes (IBGE, 2020), tem o mais alto IDH da RMC (0,819). O setor de serviços representa pouco mais da metade dos empregos formais $(53,72 \%$, IBGE, 2020) e a renda per capita é de R\$ $1570,91$.

Valinhos possui seis escolas estaduais e uma delas, a EE Américo Belluomini ampliou consideravelmente a participação de docentes precários passando de 21\%, em 2011, para 52\% em 2019. As demais reduziram para níveis inferiores à média da RMC.

Paulínia, com 112.003 habitantes (IBGE, 2020), se destaca pela elevada contribuição ao PIB estadual (SEADE, 2020) por abrigar a Petrobrás em seu território, situação essa não refletida totalmente no IDHM que fica na média da RMC: 0,795 e, relativamente, na renda per capita de $\mathrm{R} \$ 974,57$ (SEADE, 2020). A despeito da concentração de riquezas no município, essa não se reflete em melhores relações de trabalho dos docentes da rede estadual, uma vez que a média na série histórica foi de 45\%, como observado no Gráfico 5.

Entre as quatro escolas estaduais de Paulínia, uma delas (EE Francisco Mascarenhas) 
passa toda a série histórica com percentuais elevados de contratação temporária e finaliza a série, em 2019, com 53\% de docentes não efetivos; a EE José N. Vieira reduz apenas três pontos percentuais em nove anos e encerra em 2019 com 40\% de professores na mesma condição.

Gráfico 5. Docentes PEBII, não concursados, média anual, rede estadual paulista, municípios com população entre 100.001 a 500.000 hab., 2011 a 2019 (\%)

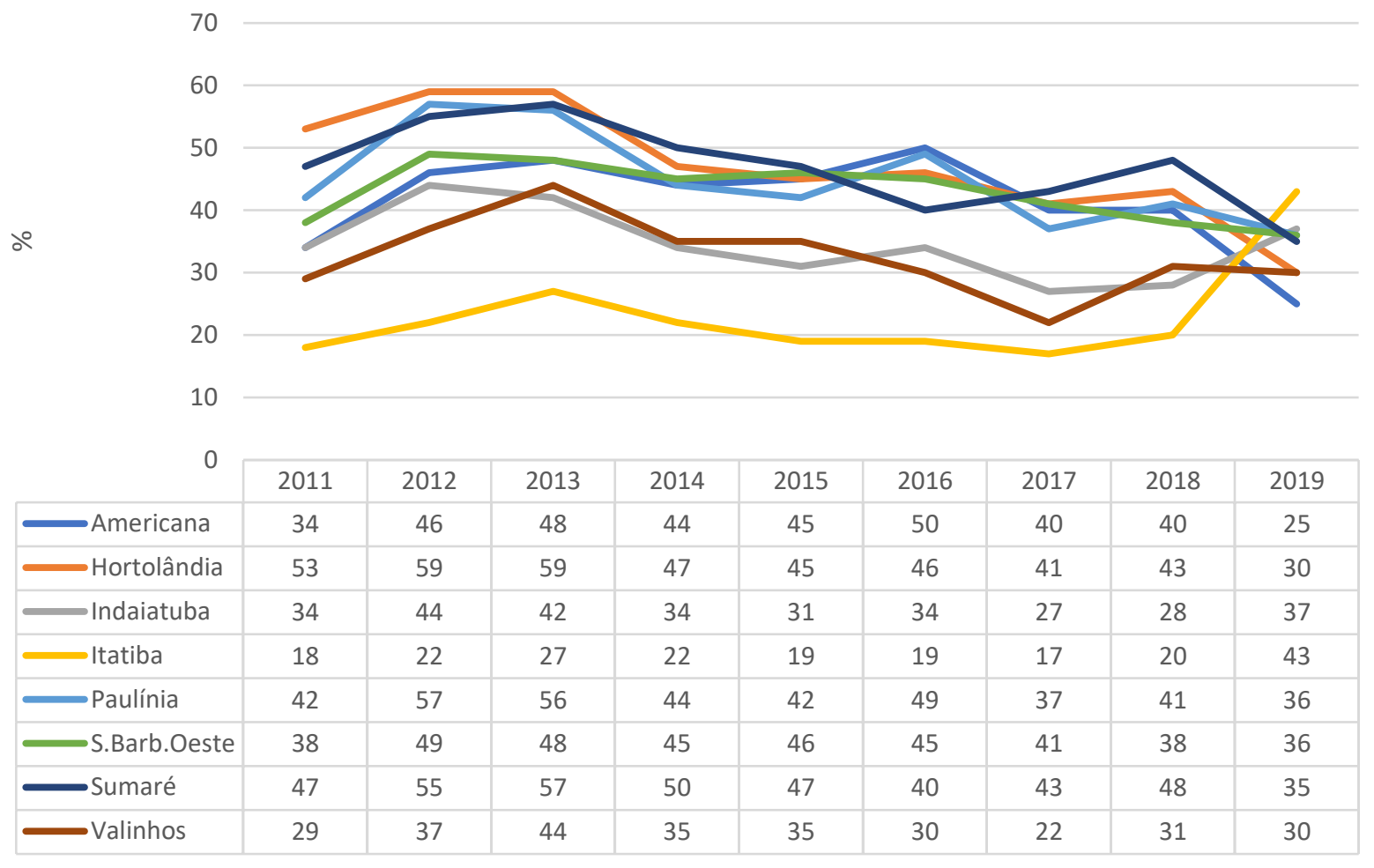

Fonte: SEDUC-SP, CGRH, 2011 a 2019. Elaboração própria.

Por fim, Campinas, responsável pela conurbação que resulta na RMC, é a metrópole que compõe a Região Metropolitana, sendo o mais povoado: 1.213 .792 habitantes (IBGE, 2020), renda per capita elevada de $\mathrm{R} \$ 1.135,29$ (IBGE, 2010), bem como o IDHM de 0,805 (PNUD, 2010).

Cunha e Falcão (2017) destacam que Campinas e alguns outros municípios da RMC, como Indaiatuba, Paulínia e Valinhos, receberam vultuosos investimentos governamentais após os anos 1970 e registraram consequente crescimento, todavia bastante desordenado e resultante de duas "cordilheiras": a da riqueza e a da pobreza. Assim, a população residente ao sul da Rodovia Anhanguera é a de baixa renda e, ao norte, o oposto. Para os autores: "Assim como na 
maioria das metrópoles, Campinas continua apresentando alta concentração de pobreza, desemprego, violência, desenvolvimento socioeconômico desigual e, sobretudo um forte grau de segregação socioespacial” (CUNHA, FALCÃO, 2017, p.10).

A partir da Imagem 1, que apresenta indicadores sociais e de vulnerabilidade social de Campinas, é possível visualizar as "cordilheiras" propostas pelos autores.

Imagem 1. Índice de Vulnerabilidade Social, município de Campinas
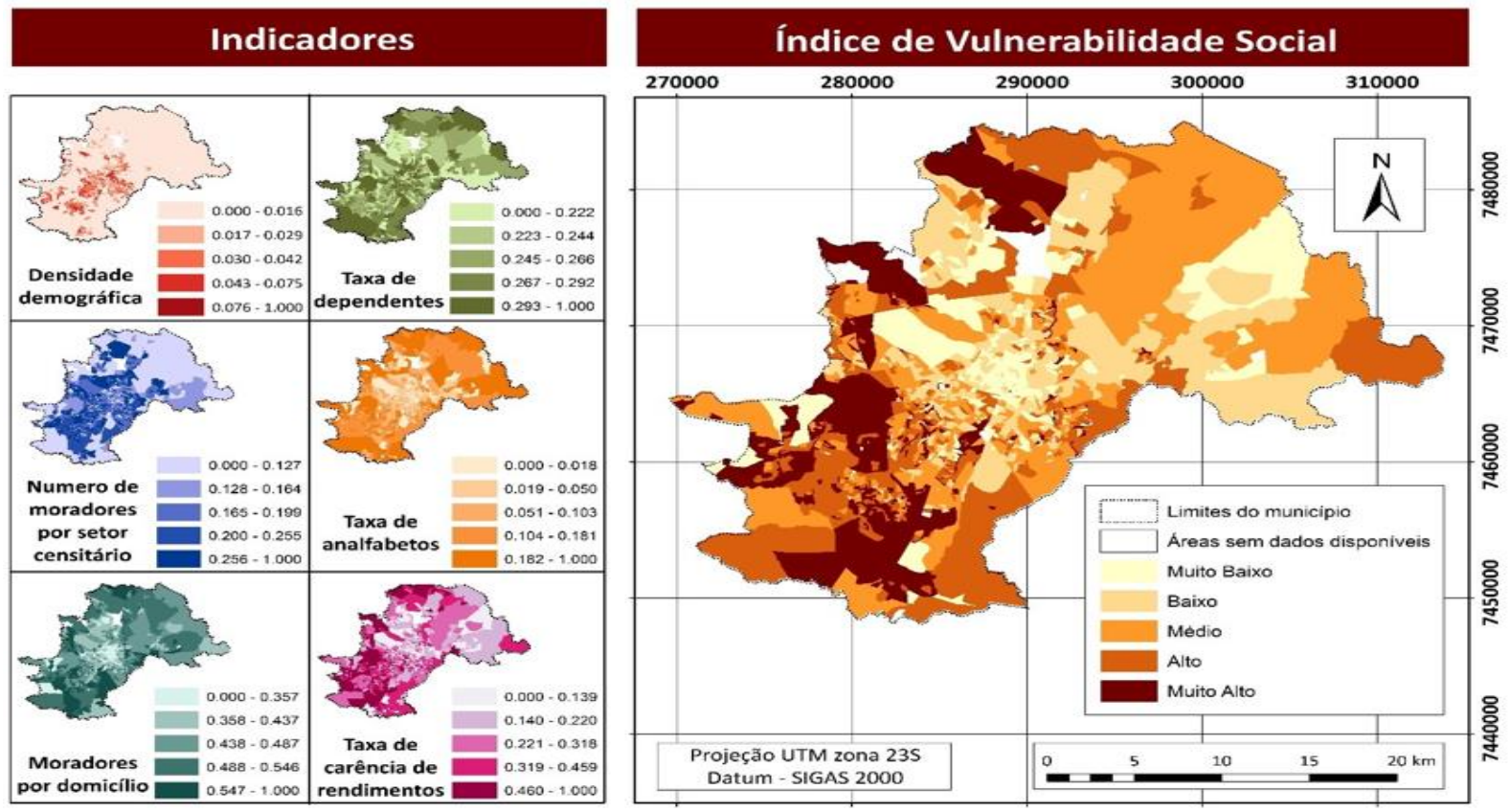

Fonte: Marques, Silva e Camargo (2017, p. 1864)

Tais dados dialogam diretamente com a quantidade de docentes não efetivos na rede estadual presentes no município (Gráfico 6), especialmente nas unidades escolares localizadas na zona oeste de Campinas e integrantes da "cordilheira de pobreza". 
Gráfico 6. Docentes PEBII, não concursados, média anual, rede estadual paulista, municípios com população acima de 500.001 hab., 2011 a 2019 (\%)

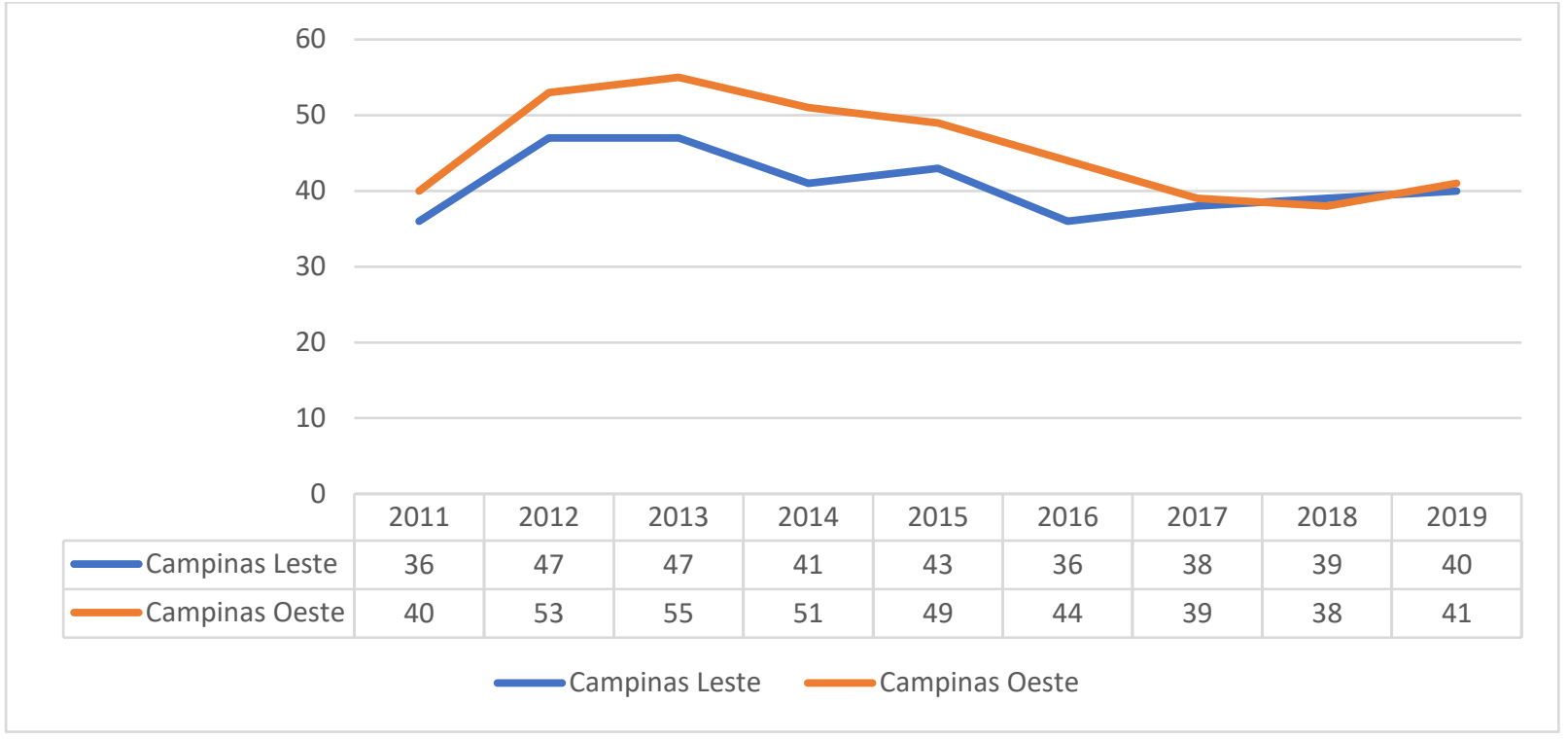

Fonte: SEDUC-SP, CGRH, 2011 a 2019. Elaboração própria.

Assim, Campinas com 76 escolas estaduais, das quais 16 registraram, em 2019, percentuais acima de $50 \%$ de contratos temporários. O destaque negativo é apontado para a $\mathrm{EE}$ Paulo Luiz Decourt que, em 2011, computava 41\% de docentes não efetivos, mas encerra a série com $100 \%$ dos professores na mesma condição. Outras como EE Antonio Mobili, Campo Grande II, Celeste Paladin Mello, Elcio Selmi atravessam toda a série histórica com patamares acima dos $50 \%$.

O mapa 1 é resultado da compilação do conjunto de dados, por escola, fornecido pela SEDUC-SP sobre os contratos firmados com professores PEB II de maneira precária, ou seja, admitidos sem concurso público. A impossibilidade de retratar no mapa a situação real e individual das escolas, oculta ocorrências em escolas que de 2011 a 2019 não contaram com nenhum professor concursado; ou outras que, sem atingir $100 \%$, mantiveram altos percentuais de ausência de professores nessa condição, como procurou-se destacar anteriormente. Assim, procedeu-se à média da RMC (39,6\%), com vistas a obter algum tipo de padronização capaz de representar o fenômeno. As escolas foram, então, classificadas entre as que comportavam percentual igual ou superior a 39,6\% e, em outro bloco, as que lograram até $39,5 \%$.

A localidade de cada escola foi sobreposta à distribuição do Índice Paulista de Vulnerabilidade Social, de forma a apreender a maior ou menor presença de precariedade na 
"cordilheira da pobreza" (CUNHA, FALCÃO, 2017), expandida à Região Metropolitana de Campinas, no oeste do mapa 1.

Mapa 1 - Distribuição de docentes com contratos precários, vinculados à rede paulista, na Região Metropolitana de Campinas, segundo Índice Paulista de Vulnerabilidade Social (\%)
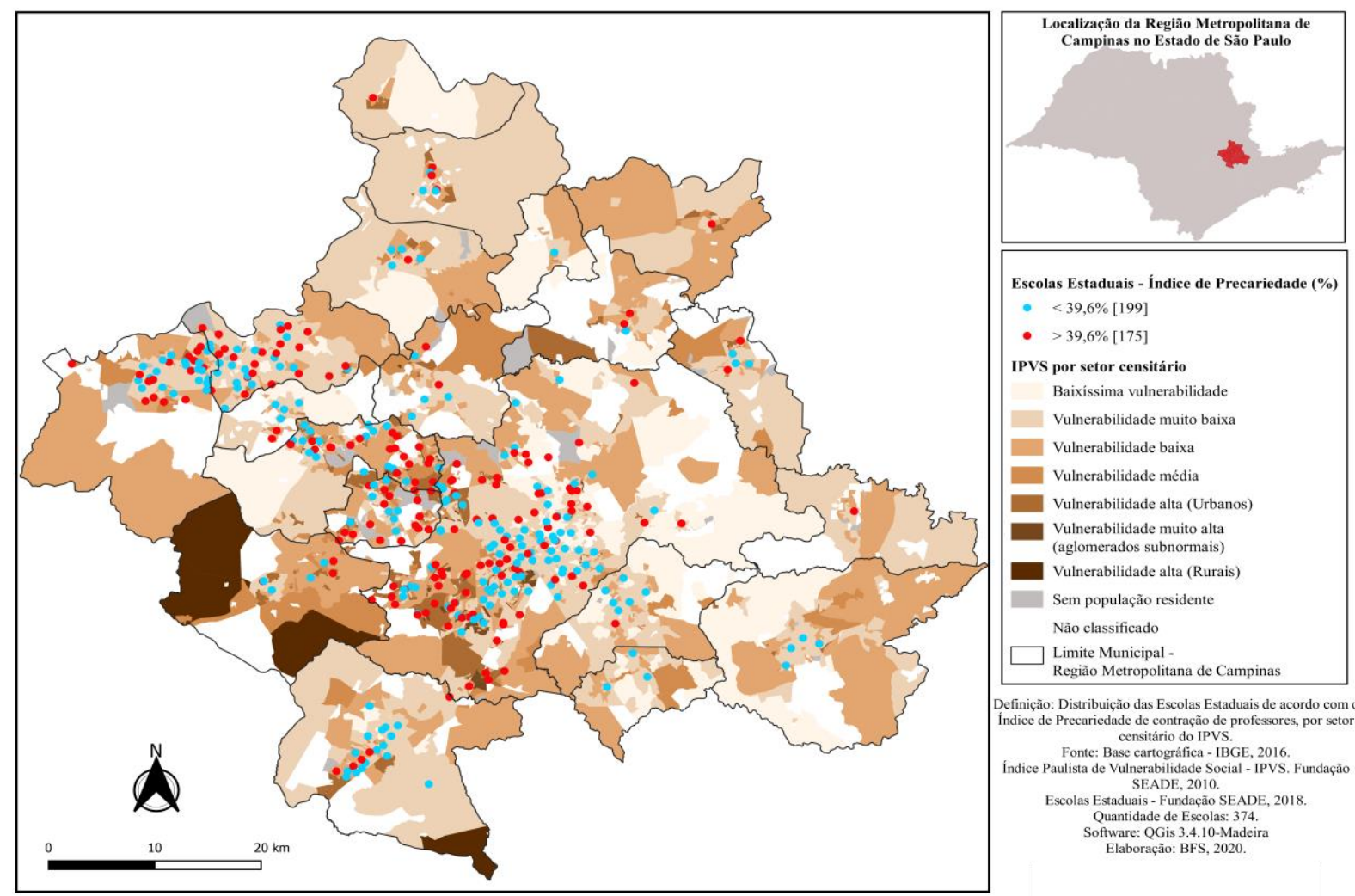

Definiçăo: Distribuiçăo das Escolas Estaduais de acordo com İndice de Precariedade de contração de professores, por setor censitário do IPVS.
ins Fonte: Base cartográfica - IBGE, 2016.
Indice Paulista de Vulnerabilidade Social - IPVS. Fundação Escolas Estaduais - Fundação SEADE, 2018 Quantidade de Escolas: 374 .
Software: QGis 3.4.10-Madeira Elaboraçăo: BFS, 2020.

Fonte: Seduc-SP, 2019, IPVS (SEADE, 2016). Elaboração própria

A tabela 1 auxilia a leitura do mapa 1 ao indicar a existência de maior quantidade de escolas com níveis superiores à média da RMC, ou seja: $54 \%$ das escolas da região enquadramse acima da média e estão localizadas em áreas de média vulnerabilidade social.

Tabela 1. Distribuição das escolas da rede estadual paulista na Região Metropolitana de Campinas, segundo níveis de precariedade média ( $\mathrm{n} 0$ abs)

\begin{tabular}{l|c|c}
\hline & $\begin{array}{c}\text { Precariedade } \\
\geq 39,6 \%\end{array}$ & $\begin{array}{c}\text { Precariedade } \\
\leq 39,5 \%\end{array}$ \\
\hline Vulnerabilidade média & 573 & 528 \\
\hline Vulnerabilidade alta (Urbanos) & 251 & 196 \\
\hline Vulnerabilidade muito alta & 28 & 23 \\
\hline Vulnerabilidade alta (Rurais) & 50 & 26 \\
\hline Total & 902 & 773 \\
\hline \multicolumn{2}{c|}{ Fonte: IPVS (SEADE, 2010); Seduc-SP, 2019 Elaboração própria }
\end{tabular}

Periódico Horizontes - USF - Itatiba, SP - Brasil - e021035 
Coaduna-se aqui à perspectiva defendida por Archela e Théry $(2008$, p.2) que: "os mapas sejam concebidos como documentos que revelam o visível e o invisível na imagem, como, por exemplo, as concepções ideológicas de uma sociedade". Assim, considera-se de grande utilidade captar a realidade da Região, analisada à luz dos dados demográficos aplicados ao território, e, a incidência de professores temporários.

\section{Uberização ou desemprego?}

A adesão da política educacional paulista ao gerencialismo já analisada por diversos autores (ADRIÃO; GARCIA, 2014; VENCO, 2016, 2018, 2020) destacam que essa ocorreu de forma mais intensa a partir de 1995, com a eleição de Mário Covas ao governo do estado e tendo Roserley Nebauer como Secretária da Educação até a atualidade. O conjunto de secretários, desde então, praticou sucessivos aperfeiçoamentos na implementação das diversas etapas concernentes à Nova Gestão Pública.

Cavalcante (2018) contribui com as reflexões sobre a Nova Gestão Pública e aponta que essa pode ser dividida em duas gerações: a primeira, difundida nos anos 1980, com ênfase na premência em adotar a lógica privada na administração pública, com vistas a romper com o Estado Burocrático a quem o neoliberalismo imputava um formato conservador e estagnado frente ao dinamismo da sociedade. São incorporadas, assim, medidas direcionadas à estandardização dos procedimentos, à mensuração de resultados, e, no caso da educação, desconsiderando a realidade das unidades escolares, do entorno da escola e, sobretudo as dificuldades individuais de aprendizagem no contexto da massificação; e, a segunda, conserva os mesmos valores adicionados à "qualidade dos serviços prestados, pelo empoderamento do cidadão no processo de escolha de serviços via competição entre os órgãos e por accountability e transparência" (CAVALCANTE, 2018, p.18). Além desses, o autor elenca uma série de características afeitas à fase pós-NGP como o estabelecimento de parcerias, atuação em redes, maior participação social, "processos empreendedores e valorização do quadro funcional do Estado, com vistas a torná-lo mais eficiente" (CAVALCANTE, 2018, p.18).

Contudo, o exame da Nova Gestão Pública (BRESSER-PEREIRA, 1998) remete à conclusão de que diversas etapas da denominada pelo autor - com base em bibliografia diversa e 
internacional - "pós-NGP” já está, por um lado, em curso desde 1995, com as Reformas do Estado e a Educacional propagadas para diversos estados, principalmente por São Paulo, correia de transmissão política do então presidente Fernando Henrique Cardoso. E, por outro, dificilmente chegará a ser concretizada dada a opção política mais selvagem adotada no estado de São Paulo, qual seja: a aniquilação da função pública, com intervalos longínquos entre concursos públicos e comprometendo, assim, a presença de profissionais da educação de caráter efetivo.

Ao focalizar somente as relações de trabalho constata-se um panorama de fragilidade na educação, em contraposição ao discurso pela qualidade do ensino. Como visto, a Região Metropolitana de Campinas registra uma média de quatro docentes, em cada dez, com situações instáveis, ministrando aulas divergentes da sua formação, estudantes sem aula, salas com lotação acima do aceitável, indicativos que a opção pela redução de custos perpassa, inclusive, a contratação de docentes substitutos (VENCO, 2020).

Inscreve-se nesse cenário a nova vaga no mundo do trabalho denominada uberização ou uberismo (VENCO, 2019), embalada pelo princípio da economia do compartilhamento, também difundida como gig economy (economia de bico), cujo engodo inicia-se pela própria designação: segundo Slee (2017, p.24) a ideia de compartilhar remete a "uma interação social, entre iguais e sem caráter comercial". Porém, essa face recente da esfera produtiva, cujo princípio é conectar consumidores e prestadores de serviços, deu margem à construção de verdadeiros impérios, a exemplo da Uber que contava, no Brasil, com 1 milhão de motoristas e 22 milhões de usuários (UBER, 2021). A empresa retém $25 \%$ de cada viagem feita pelo motorista, esse sem nenhum tipo de vínculo empregatício, sem qualificação prévia para conduzir passageiros - diferente dos condutores de táxi, obrigados por lei a pagarem além de impostos, de serem certificados em diversos cursos - e, além disso, arcam com todos os custos do veículo, do celular, da manutenção de ambos, sempre sujeitos a acidentes e outros danos.

Os discursos acríticos exaltaram a vida sem patrões, a liberdade de horário e de ganhos aos aderentes aos serviços de plataforma, mas escamotearam a profunda desregulamentação do trabalho e do emprego que suscitaria, via a adesão do empresariado ao modismo, apoiada na Reforma Trabalhista de 2017, cuja promessa do governo Temer (2016-2019) era a criação de um incontável número de novos empregos.

Da empresa Uber à conjugação do "verbo" uberizar remonta-se ao pagamento por peça, 
dimensão estreitamente associada à intensificação do trabalho:

Dado o salário à peça, é naturalmente do interesse pessoal do operário empregar a sua força de trabalho tão intensivamente quanto possível, o que facilita ao capitalista uma elevação do grau normal da intensidade. É igualmente do interesse pessoal do operário prolongar o dia de trabalho, porque assim o seu salário diário ou semanal. Ocorre assim a reação já descrita em relação ao salário por tempo, independentemente do fato de o prolongamento do dia de trabalho, mesmo quando o salário à peça permanece constante, encerrar em si e por si um abaixamento do preço do trabalho (MARX, 1982 p.640).

Assim, face à fase recente da uberização do trabalho (HUWS, 2014), marcada pelo fim dos direitos, ausência da figura do empregador e forte apelo ao empreendedorismo individual, visa-se estabelecer paralelos com a política de contratação de professores adotada pelo governo paulista.

Como destacado, a "plataformização" do trabalho ultrapassa os limites da mediação entre clientes e consumidores via internet, mas inaugura uma nova forma de exploração da força de trabalho e exime empresa e Estado das incumbências sociais envolvidas nas relações de trabalho.

Estudos desenvolvidos talharam a comparação entre motoristas da Uber e docentes. As entrevistas realizadas ao longo dos anos indicam que a jornada indefinida dos professores, os quais necessitam buscar em diversas escolas uma quantidade de aulas capaz de permitir a mínima sobrevivência e, assim como os concursados, estão em permanente avaliação e disponibilidade, pois, ao contrário, não serão novamente chamados pela direção.

Assim, as duas categorias profissionais precisam estar permanentemente disponíveis, pois os ganhos dependem do pagamento por peça, como alertava Marx (1982).

Além da jornada, ambos não carecem de qualificação apropriada para seu exercício. $\mathrm{Na}$ Uber qualquer condutor é considerado, enquanto os motoristas de táxi devem obrigatoriamente obter certificados em diversos cursos. No caso dos professores há marcos legais, a exemplo da Portaria DRHU, no 12/1999, que admitia estudantes de graduação matriculados no segundo semestre do curso a atuarem como docentes e, ainda: atuando em áreas não correlatas aos estudos em desenvolvimento (VENCO, 2016). Destaque-se a alteração dessa medida em 2017, mas ainda assim estudantes que tenham cursado metade da graduação são admitidos. Os 
bacharéis oriundos de áreas como direito, contabilidade, engenharia entre outras (VENCO, 2018, 2020), também puderam ser contratados, mesmo que sem nenhuma formação destinada às práticas pedagógicas, à política e à psicologia educacional, aos conteúdos inscritos nos programas de formação de professores.

Admite-se, consequentemente, a presença de aspectos na uberização do trabalho que não são, de fato, novos. Há importantes permanências causadoras da instabilidade e da precarização das condições de vida dos professores. Se ainda não estão em situação igualitária à dos motoristas de plataforma, concebe-se que experienciam um grau de volubilidade há pelo menos duas décadas e que se expande ao longo dos anos.

Concebe-se, no presente artigo, estar em curso uma nova fase de depreciação do trabalho docente, manifesta de diversas formas. A valorização profissional, ainda que reafirmada pela Lei de Diretrizes e Bases, Lei no 9394 (BRASIL, 1996), é amplamente desconsiderada nas políticas paulistas: foram criados cadernos do professor e controle do trabalho docente, em nítida tentativa de subordinar o trabalho intelectual intrínseco à profissão, a exigência de cumprimento de metas inexequíveis, a aplicação de métodos de melhoria de resultados.

Julga-se imprescindível problematizar as transformações pelas quais a educação básica já emitia sinais de incorporação de mecanismos aptos a reduzir a presença dos docentes nas escolas. O Decreto no 9.057 (2017) permitia a adoção da educação a distância à educação básica e, em 2019, a Portaria de no 2.117 ampliou a carga horária passando-a de 20 para 40\% nessa modalidade.

Medidas legais admitiram que o ensino híbrido se transformasse em realidade, antes da crise sanitária vivenciada tristemente no país pela COVID19. O distanciamento social provocado pela pandemia pavimentou acesso livre o qual, supõe-se, será altamente lucrativo tendo em vista a rapidez em que se deu a criação da Associação Nacional Educação Básica Híbrida (ANEBHI, 2020), autodeclarada sem fins lucrativos e presidida por Maria Inês Fini - cujo currículo a aponta como mentora do conjunto de políticas adotadas no Ministério da Educação e na SEDUC-SP desde os anos 1995 (VENCO, EVANGELISTA, 2020).

Os dados estatísticos sobre os professores efetivos e não efetivos associados a esses aspectos sinalizam possibilidades concretas de desemprego a essa categoria profissional. Em 1999 a Secretaria da Educação do estado de São Paulo contava com 204.776 docentes, dos quais 
73\% eram não efetivos; em 2019 a situação reverte-se e são, agora, 76\% efetivos. Entretanto, registre-se, houve uma supressão de 52.000 postos de trabalho para professores.

Pondera-se que a racionalidade econômica, que ao longo dos últimos 26 anos, tem regido o governo paulista, somada à implementação do ensino híbrido resultará, caso tal política permaneça, em fechamento de salas e escolas e continuará o movimento decrescente de docentes na rede estadual.

\section{Considerações finais}

O artigo buscou problematizar o fenômeno da precariedade nas relações de trabalho praticada pelo governo paulista junto aos docentes que atuam nos ensinos fundamental II e médio nos vinte municípios que integram a Região Metropolitana de Campinas.

A pressuposição inicial referente ao fato de que as áreas com maior vulnerabilidade social concentram maior número de contratos precários entre os docentes se verifica, ainda que com importantes ocultamentos que se pretende aprofundar na fase seguinte do estudo ora apresentando, qual seja: a visita às escolas, com vistas a caracterizar o entorno da unidade escolar aliado às entrevistas com docentes.

Municípios, a exemplo de Arthur Nogueira, simbolizam a relação de pobreza e precariedade docente em graus mais extremados, cujas causas se constituem como objeto de análise ainda em curso; outras escolas isoladas também comprovam a hipótese aventada, pois registraram percentuais próximos a $100 \%$ relativos à precariedade praticada junto aos professores.

As formas flexíveis de contratação são parte da história do país, sendo mais recente sua prática no setor público, em especial com o advento da Nova Gestão Pública iniciada com a adesão ao neoliberalismo desde o governo Fernando Collor, após ditadura empresarial-militar e consolidada no governo FHC. Essas foram adquirindo contornos de perda de direitos e instabilidade, em razão da curta duração dos contratos.

Constatou-se que há uma política generalizada de redução de docentes, não apenas os temporários, apoiada em diversas medidas, entre elas o fim do ensino no período noturno, o qual afeta diretamente os estudantes trabalhadores. A ausência de concursos públicos para 
professores, ou o realizado para supervisores de ensino, mas sem a convocação dos aprovados, constituem indícios do caminho para redução importante da quantidade de profissionais da educação e, supõe-se, haverá uma nova vaga na educação paulista com fortes processos de terceirização de serviços.

Os docentes já vivenciam situações semelhantes aos motoristas uberizados, pois estão sempre disponíveis, o rendimento é incerto, cujo grau de instabilidade financeira pode ser sintetizado pela máxima: se não trabalhar, não come, não mora.

Problematiza-se, assim, se tal situação está em vias de se tornar ainda mais permanente e ou mais grave. Como visto, cabe indagar se a política educacional irá tirar proveito do contexto da pandemia para impulsionar outros mecanismos dispensadores do professor na sala de aula, a exemplo da ampla adoção do ensino híbrido, braço maleável da educação a distância que replicará conteúdos via internet e outros meios, eliminando a quantidade de profissionais consideravelmente que, de fato, na lógica adotada, não necessariamente precisam ser docentes.

E, assim, aguardar-se-á o avanço tecnológico rumo à inteligência artificial para eliminação de um profissional que, timidamente, já foi, em tempos ábditos, aclamado pela sociedade como fundamental à formação da Nação?

\section{Referências}

ADRIÃO, T.; GARCIA, T. Subsídio público ao setor privado: reflexões sobre a gestão da escola pública no Brasil. Políticas Educativas, Porto Alegre, v.7, n.2, p.110-22, 2014.

ANEBHI. Sobre. Disponível em: https://anebhi.com/sobre. Acesso em: 25 jan.2021.

ARCHELA, R.; THÉRY, H. Orientação metodológica para construção e leitura de mapas temáticos. Confins, França, Brasil, v.3, p.1-21, 2008.

BRASIL. [Constituição (1934)]. Constituição da República Federativa dos Estados Unidos do Brasil. DF: Presidência da República Disponível em:

http://www.planalto.gov.br/ccivil_03/constituicao/constituicao34.htm. Acesso em: 28 out. 2020.

BRASIL. [Constituição (1937)]. Constituição da República Federativa dos Estados Unidos do Brasil. DF: Presidência da República. Disponível em:

http://www.planalto.gov.br/ccivil_03/constituicao/constituicao37.htm. Acesso em: 28 out. 2020.

Periódico Horizontes - USF - Itatiba, SP - Brasil - e021035 
BRASIL. [Constituição (1946)] Constituição da República Federativa dos Estados Unidos do Brasil, DF: Presidência da República.

Disponível em: http://www.planalto.gov.br/ccivil_03/constituicao/constituicao46.htm. Acesso em: 28 out. 2020.

BRASIL. [Constituição (1988)]. Constituição da República Federativa do Brasil de 1988., DF: Presidência da República. Disponível em: http://www.planalto.gov.br/ccivil_03/Constituicao/ Constituiçao.htm. Acesso em: 11 ago. 2020.

BRASIL. Lei no 9.394, de 20 de dezembro de 1996. Estabelece as diretrizes e bases da educação nacional. Disponível em: http://www.planalto.gov.br/ccivil_03/leis/19394.htm. Acesso em: 15 mar. 2021.

BRASIL, Decreto no 9.057, de 25 de maio de 2017. Regulamenta o art. 80 da Lei $n=9.394$, de 20 de dezembro de 1996, que estabelece as diretrizes e bases da educação nacional. Disponível em: https://www2.camara.leg.br/legin/fed/decret/2017/decreto-9057-25-maio-2017-784941publicacaooriginal-152832-pe.html. Acesso em: 15. mar. 2021.

BRASIL. Portaria no 2.117, de 06 de dezembro de 2019. Dispõe sobre a oferta de carga horária na modalidade de Ensino a Distância - EaD em cursos de graduação presenciais ofertados por Instituições de Educação Superior - IES pertencentes ao Sistema Federal de Ensino. Disponível em: https://www.in.gov.br/en/web/dou/-/portaria-n-2.117-de-6-de-dezembro-de-2019232670913. Acesso em: 15 mar. 2021.

BRASIL, IBGE. Indicadores sociais municipais. Estudos e Pesquisas Informação Demográfica e Socioeconômica. Brasília, n.14, 2004. Disponível em https://biblioteca.ibge.gov.br/visualizacao/livros/liv4711.pdf. Acesso em 18.jan.2021.

BRASIL, IBGE. Estimativas da população residente no Brasil e unidades da Federação com data de referência em 1ㅇ de julho de 2020. Disponível em https://ftp.ibge.gov.br/Estimativas_de_Populacao/Estimativas_2020/POP2020_20210331.pdf.

BRASIL, IBGE, Cidades, 2020. Disponível em: https://cidades.ibge.gov.br/. Acesso em: 18 jan. 2021.

BRASIL, IBGE, Cidades, Renda per capita 2017. Disponível em: https://cidades.ibge.gov.br/. Acesso em: 10. mai. 2021.

BRASIL, IBGE. Produto Interno Bruto. Disponível em https://www.ibge.gov.br/explica/pib.php. Acesso em 01.mai.2021.

BRASIL, INEP. Censo educacional, 2011 a 2019.

BRESSER-PEREIRA, L. C. Reforma do estado para a cidadania: a reforma gerencial brasileira na perspectiva internacional. São Paulo: Editora 34, 1998. 
CASTEL, R. As metamorfoses da questão social: uma crônica do salário. Petrópolis: Vozes, 1998.

CAVALCANTE, P. Convergências entre a governança e o pós-nova gestão pública. IPEA, 2018, p.17-24. Disponível em:

http://repositorio.ipea.gov.br/bitstream/11058/8965/1/bapi_19_cap_03.pdf. Acesso em: 21 jan. 2021.

CUNHA, J. M., FALCÃO, C. (orgs.) Campinas metropolitana: diversidades socioespaciais na virada do século XXI. Campinas: Librum, 2017.

DEDECCA, C S. Notas sobre a evolução do mercado de trabalho no Brasil. Brasil. J. Polit. Econ., São Paulo, v.25, n.1, p.113-130, mar. 2005. Disponível em:

http://www.scielo.br/scielo.php?script=sci_arttext\&pid=S0101-

$31572005000100006 \&$ Ing=en\&nrm=iso. Acesso em: 29 out. 2020. DOI:

https://doi.org/10.1590/0101-35172005-1640.

DELGADO, M. G. Curso de direito do trabalho. São Paulo: LTR, 2007.

FAORO, R. Os donos do poder - formação do patronato político brasileiro. 13. ed. São Paulo, Globo, 1988.

FUNDAÇÃO SEADE. Índice paulista de vulnerabilidade social, 2016. Disponível em: http://catalogo.governoaberto.sp.gov.br/dataset/21-ipvs-indice-paulista-de-vulnerabilidadesocial. Acesso em: 01.mai. 2021.

FUNDAÇÃO SEADE. Perfil dos municípios paulistas. São Paulo, 2020. Disponível em: http://www.perfil.seade.gov.br/. Acesso em: 01.mai. 2021.

GOLLAC, M., VOLKOFF, S. Les conditions de travail. Paris: La Découverte, 2007.

GOUNET, T. Fordismo e toyotismo na civilização do automóvel. São Paulo: Boitempo, 1999.

HARVEY, D. A produção capitalista do espaço. São Paulo: Annablume, 2006.

HUWS, U. Labor in the global digital economy. New York: Monthly Review Press, 2014.

LINHART, R. L'établi. Paris: Minuit, 1978.

MARQUES, M. L.; SILVA, M C.; CAMARGO, D. M. Análise espacial da vulnerabilidade socioambiental no município de Campinas, SP, Brasil. Revista Brasileira de Cartografia, n.69, v. 9, p.1857-1870, 2017.

MARX, K. O capital: crítica da economia política, livro 1: o processo de produção do capital, vol. 2. São Paulo: Difel, 1982. 
MOREIRA JÚNIOR, O. Uma leitura geográfica dos papéis e significados de cidades pequenas na região metropolitana de Campinas-SP. Revista do Departamento de Geografia - USP, v.29, p.79-99, 2015.

NERY, M. B.; SOUZA, A. A. L.; ADORNO, S. Os padrões urbano-demográficos da capital paulista. Estudos Avançados, v.33, n.97, p.5-36, 2019. Disponível em: https://www.scielo.br/scielo.php?script=sci_arttext\&pid=S0103-40142019000400005. Acesso em: 30.abr.2021.

PROGRAMA NAÇÕES UNIDAS BRASIL (PNUD). Atlas do desenvolvimento humano dos municípios, 2010. Disponível em: https://www.br.undp.org/content/brazil/pt/home/idh0/atlasdo-desenvolvimento-humano/atlas-dos-municipios.html. Acesso em: 15.mar.2021.

RODGERS, G., Precarious work in Western Europe: the state of the debate. In: RODGERS, G., RODGERS, J. Precarious jobs in labor market regulation: the growth of atypical employment in western Europe. Brussels: International Labor Organisation, 1989, p.1-16.

SÃO PAULO [PROVÍNCIA]. Lei no 81, de 06 de abril de 1887. Disponível em: https://www.al.sp.gov.br/repositorio/legislacao/lei/1887/lei-81-06.04.1887.html. Acesso em: 25 jan. 2021.

SÃO PAULO [ESTADO]. Lei no 500, de 13 de novembro de 1974. Institui o regime jurídico dos servidores admitidos em caráter temporário e dá providências correlatas. Disponível em: https://www.al.sp.gov.br/repositorio/legislacao/lei/1974/original-lei-500-13.11.1974.html. Acesso em: 28 out. 2020.

SÃO PAULO [ESTADO]. Secretaria da Educação do Estado de São Paulo. Portaria DRHU no 12, de 14 de dezembro de 1999. Disponível em:

http://www.imprensaoficial.com.br/DO/BuscaD02001Documento_11_4.aspx?link=/1999/exec utivo\%2520secao\%2520i/dezembro/15/pag_0011_DQQVA86RKGO4Ke824F0U3RO24RM.pdf\& pagina $=11 \&$ data $=15 / 12 / 1999 \&$ caderno=Executivo\%20I\&paginaordenacao=10011. Acesso em: 15 mar. 2021.

SINGER, P. O uso do solo urbano na economia capitalista. In: MARICATTO, E. (org.). A produção capitalista da casa (e da cidade) no Brasil industrial. 2. ed., Alfa-Ômega, São Paulo, 1982, p.7790.

SLEE, T. Uberização: a nova onda do trabalho precarizado. São Paulo: Elefante, 2017.

UBER. Disponível em: https://www.uber.com/pt-BR/newsroom/fatos-e-dados-sobre-uber/. Acesso em: 25 jan. 2021.

VENCO, S. Terceirização nos tempos do cólera: o amor do setor público pela precariedade. Argumentos Pró-Educação, Pouso Alegre, n.3, v.1, p.392-407, 2016. 
VENCO, S. Situação de quasi-uberização dos docentes paulistas. Revista ABET, v.17, p.94-104, 2018. Disponível em: http://www.periodicos.ufpb.br/index.php/abet/article/view/41167. Acesso em: 15 mar. 2021.

VENCO, S. Uberização do trabalho: um fenômeno de tipo novo entre os docentes de São Paulo, Brasil. Cad. Saúde Pública, Rio de Janeiro, v.35, supl.1, p.1-17, 2019. Disponível em: http://www.scielo.br/scielo.php?script=sci_arttext\&pid=S0102311X2019000503003\&Ing=en\&nrm=iso. Acesso em: 06 mar. 2021. e00207317. DOI: https://doi.org/10.1590/0102-311x00207317.

VENCO, S. A docência em instituições públicas da educação básica no Brasil do século XXI: precariedade e ocaso da função Pública. In: DELGADO, G. N. (org.). Direito fundamental ao trabalho digno no século XXI, vol II. Brasília: LTR, 2020. p.208-218.

VENCO, S. EVANGELISTA, O. Crise sanitária e legado educacional: a cilada do ensino híbrido. Universidade à esquerda, 21 out. 2020. Disponível em:

https://universidadeaesquerda.com.br/coluna/crise-sanitaria-e-legado-educacional-a-ciladado-ensino-hibrido/. Acesso em: 15.mar.2021.

VENCO, S.; SOUSA, F. O crepúsculo da função pública: distopia ou realidade? Revista Educación, Política Y Sociedad, n.6, v.1, p.149-176, 2021. Disponível em:

https://doi.org/10.15366/reps2021.6.1.006. Acesso em: 30.abr.2021.

Recebido em janeiro 2021.

Aprovado em março 2021. 